\title{
Opportunity cost of Nigeria's external reserves
}

\author{
Udo, Aniefiok Benedict; Antai, Agnes Syvester (PhD) \\ Department of Economics, University of Calabar, Calabar-Nigeria \\ +2348034042129, +2348127735130 aniefiok.benedict@gmail.com \\ Department of Economics,University of Calabar, Calabar-Nigeria \\ +2348037236629, +2348124216691 asylvesterantai@gmail.com
}

\begin{abstract}
The external reserve-economy relationship argument has generated debate due to unsatisfactory theoretical and empirical consensus. There is an ongoing debate on whether having large holding of international reserves is beneficial or not. The critics' main argument is that those resources could and should be used in a more productive manner to develop the domestic economy. In Nigeria, in spite of successfully guiding the economy to a stable inflation rate of 15.1 in 2008 in the face of an unprecedented growth of external reserves the overall domestic picture has remained stark. The country has been experiencing resource underutilization, high incident of poverty and decay of infrastructures. Besides, Nigeria's external debt has been rising over the years, in spite of the debt relief in 2005. This study, therefore, investigated the impact of Nigeria's foreign reserves on the domestic economy, using both descriptive and econometric analysis. In the descriptive analysis, Greenspan-Guidotti method was used for the annual time series data on reserves accumulation from 1970 to 2011 while two multiple regression model were formulated, in the econometric analysis, to test the impact of external reserves on the domestic economic level and to check the effect of external reserves on the domestic investment. The results show that external reserves negatively influence the level of domestic economic productivity and investment. Therefore, the Nigerian government should reduce the level of excess reserves and rather use it for investment in the domestic economy.
\end{abstract}

\section{Introduction}

The external reserve-economy relationship argument has generated debate due to unsatisfactory theoretical and empirical consensus. Since the Asian financial crisis in 1997, the world has seen foreign currency reserves holdings in Asian countries skyrocket. China and India rank as second and fifth in foreign currency reserve holdings in the world. The Asian emerging countries reserve makeup approximately $40 \%$ of the world foreign currency holdings, this being the highest in history (Aizenman, 2002). Because of this, it is interesting to examine the factors that are driving this increase in reserves. It is important to examine why countries would hold large amounts in reserves. There is an ongoing debate on whether having large holding of international reserves is beneficial or not. The critics' main argument is that those resources could and should be used in a more productive manner to develop the domestic economy, such as investing in building roads, bridges and schools (Aizenman and Marion, 2003).

On the other hand, those who support large holdings of reserves argue that the opportunity cost of holding the foreign reserves is small compared to the economic consequences of sharp devaluation of the currency (Aizenmanand Marion 2004). Reserves are held to control the exchange rate of a currency and prevent devaluations. This is done by purchasing and selling the country's own currency in order to affect its demand and supply; thus, helping to maintain a stable value in the international markets. This argument is valid mostly for developing economies, whose debt is mostly denominated in foreign currencies and would be greatly affected by devaluation. Clearly, there are pros and cons to holding large amounts of foreign reserves. However, regardless of whether reserves are held as self insurance or as ways to manage the exchange rate system, there have to be variables that help determine the optimum level.

In the Nigerian context, from the late 1990s to the present, accumulation of foreign reserve by Nigerian government has shown some profound features, with reference to size, pace, and ownership categorizations. The figure for 1996 was $\$ 3.40$ billion, but rose sharply to $\$ 28.28$ billion and about $\$ 53.00$ billion in 2005 and 2009, respectively as evident from CBN records (2010). The reasons behind this development were documented by Soludo (2005) and Nda (2006) without ethnographic examination of taming capacity underutilization, instability in domestic prices, internal debt, electricity problems, and the risk/cost of reserve holding or accumulation.

It is surprising, that the stance of external reserve holding has generated serious concern as different economies search for alternative strategies that will protect their economies against financial instability and stimulate economic growth. This is because there will be increase in economic productivity resulting from the marginal benefit if the reserve is pumped into domestic investment to stimulate economic productivity. Also, the 
elasticity of reserve accumulation to the degree of unlikely financial shocks affects the forgone utilizationbenefits.

The financing of the prolonged and substantial accumulation of foreign exchange reserves has implications for the balance sheets of the central bank, the banking system and, indeed, the private sector. Major shifts in balance sheet variables can eventually have significant macroeconomic effects which depend both on how the associated risk exposures are managed and on how the reserves are financed.

In this regard, this research paper seeks to provide answers to the following questions:

1. What level of Nigerian external reserves is needed to insure against liquidity problems? (Reserve adequacy)

2. What is the impact of the Nigeria external reserve on the domestic economy?

\section{Methodology}

This study will make use of an econometric method to analyze the questions that were formulated in the introductory section. The data will be annual data from the World Bank statistical fact sheet for Nigeria and CBN statistical bulletin of various years. Two multiple regression model will be formulated, one to test the impact of external reserves on the domestic economic level while the second will be to check the effect of external reserves on the domestic investment.

\section{LITERATURE}

\section{Evolution of external reserve management and trends in Nigeria's external reserves}

Before the inception of the Central Bank of Nigeria in 1959, the country formed part of the defunct West African Currency Board (WACB). During the period, management of external reserves posed little or no problems to the country because the manner in which the Board operated prevented such problems from arising. Optimal deployment of reserves then was really not an issue since Nigeria's non-sterling earnings were deposited in London in exchange for credit entries in the sterling accounts maintained there (Aligwekwe, 1978).

Subsequently, the 1959 Act which established the Central Bank of Nigeria (CBN) required the Bank to hold external reserves solely in Gold and Sterling. With the amendment in 1962 of this Act, the Bank acquired the mandate to maintain the country's foreign exchange reserves not only in sterling balance but also in nonsterling assets such as gold coin or bullion, bank balances, bills of exchange, government and governmentguaranteed securities of countries other than Britain and treasury bills in other countries. The monetary options available to the country widened upon joining the International Monetary Fund (IMF) in 1961 to include many more assets. The problems of reserve management began during the periods of the First National Development Plan in 1962 to 1966 and the Nigerian Civil War of 1967- 1970. During these periods, financing the plan and the war consumed a large portion of the country's reserves. Also, the tempo in the foreign trade sector dropped, following the disruption of economic activities in the country. The problems became compounded immediately after the war in the wake of the Federal Government's efforts to reconstruct and reactivate the war ravaged economy which continued to demand immense foreign exchange reserves. Because of the exigencies of this period, the CBN became committed to maintaining an 'adequate' level of external reserves.

In addition to the problem of depleting reserves, Nigeria faced a new scenario with reserve management. Following the country's, admission to the Organization of Petroleum Exporting Countries (OPEC) in 1973 and the oil boom of that era, the problem of reserve management switched from that of 'inadequate' to that of 'excess reserves'. This remained so until 1981 when the country was hit by the global economic recession that led to a consistent decline in her external reserves (Odozi, 1986). In the light of this development, economic stabilization measures involving stringent exchange control, which ran from April 1982 to June 1986 (when accretion to external reserves was low), were introduced. By the end of 1985, it was evident that the use of stringent economic controls was ineffective in restraining external reserves depletion. To this end, exchange and trade controls were discontinued in 1986, following the adoption of market based policy measures the Structural Adjustment Programmed (SAP) in July 1986. However, after more than seven years of liberalization, government felt that the overall performance of the economy was unsatisfactory. Hence, in January 1994, some measures of control were re-introduced which saw the CBN as the sole custodian of foreign exchange and, together with its designated agents, the avenues for foreign exchange importation.

Again the trade and exchange policies in 1994 failed substantially to achieve the desired objectives. The guided deregulation introduced in 1995, among other things, abolished the 1962 Exchange Control Act, in a bid to enhance the flow of capital and the reserves position of the country. Other measures aimed at boosting the external reserves included the introduction of an Autonomous Foreign Exchange Market (AFEM) for the purpose of trading in foreign currencies at market determined rates and further liberalization of the foreign exchange system in 1997 and the trade and exchange regime in 1998. 


\section{Recent trends in Nigeria's external reserves}

Nigeria's external reserves have been fluctuating over the years. Initially, the level rose from US\$0.70 billion in 1992 to US $\$ 1.30$ billion in 1993 and further to US\$1.70 billion in 1994. After falling by 17.70 per cent to US\$1.40 billion in 1995 , external reserves rose by 192.90 per cent to US\$4.10 billion in 1996 . In 1997 , Nigeria's gross external reserves stood at US\$7.58 billion and dropped by 6.30 per cent to US\$7.10 billion in 1998. Reserves dropped further by 22.50 per cent in 1999 to US $\$ 5.50$ billion. The end of year gross reserves declined by 23.30 per cent from end- December 2001 level of US\$10.42 billion to US\$7.99 billion in 2002. It declined further by 6.50 per cent to US $\$ 7.47$ billion in 2003 . The level of reserves in 2003 could support 6.50 months of imports compared with 13.60, 12.00 and 10.10 months in 2000, 2001 and 2002 respectively. Reasons for the downward trend in reserves were the inadequacy of foreign exchange receipts, coupled with huge fiscal spending and the consequent pressure on the country's payments obligations.

It must be mentioned that Nigeria is a mono-cultural economy with heavy reliance on crude oil whose price is exogenously determined. Hence, the reserves position of the country at any given point in time is usually a reflection of the circumstances prevailing in the international oil market. Following the huge receipts from crude oil sales and the prudent fiscal and monetary policy stance under the National Economic Empowerment and Development Strategy (NEEDS) introduced in 2004, trends in the country's reserves took a dramatic upward turn, The stock of external reserves which was US\$7.47 billion at end December 2003, increased by 127.00 per cent to US\$16.96 billion in 2004. The reserve position in 2004 could finance 18.40 months of imports. The import cover was much higher than the West African Monetary Zone (WAMZ) minimum requirement of 6 months. In 2005 the stock of external reserves increased further by 66.80 per cent to US $\$ 28.28$ billion. The reserve position could support 19.70 months of imports. In 2006, reserves rose to an all time high of US $\$ 42.20$ billion, supporting a staggering 28 months of imports. The Gross External Reserves as at end-October, 2007 was US\$49.12 billion. The current level of gross external reserves could support about 20 months of current foreign exchange disbursements. Efficiency in reserves management could be viewed beyond the months of import cover, to the actual amount saved in the year. In other words, the accretion to the external reserve account is very crucial in reserve management. In 1997, accretion to reserve was US\$3.50 billion. This saving was, however, not sustained in the subsequent years, resulting in a net draw down of US\$0.50 billion and US\$1.60 billion in 1998 and 1999 respectively. With the improvement in crude oil price in 2000, the external sector outcome resulted in an accretion of US $\$ 4.50$ billion, but this again dropped by US\$0.50 billion in 2001 and further by US $\$ 2.43$ billion and US $\$ 0.50$ billion in 2002 and 2003 , respectively. This trend reveals the expenditure profile of government, in which years of huge savings or gains in the net position of foreign exchange transactions are followed by periods of increased expenditure, as reflected in the net flow position in the balance of payments.

Generally, a volatile fiscal policy is not consistent with a sustainable external reserves management. A prudent fiscal policy will enhance the viability of Nigeria's balance of payments and strengthen the stability of the exchange rate. With the combined effect of positive terms of trade occasioned by high international prices of crude oil and prudent fiscal policies that followed after 2003, the downward trend reversed with accretion to external reserves increasing by US\$9.49 billion, US\$11.32 billion and US\$13.95 billion in 2004, 2005 and 2006 respectively. Osabuohien and Egwakhe (2008) Countries that may be vulnerable to a capital account crisis can benefit from holding reserves sufficient to cover all debt obligations falling due within the coming year. This is relevant in measuring vulnerability to capital account crisis. In the Nigeria case, the reserve/debt ratio has been substantially low over the years.

In 2005, however, the ratio which stood at 1.40 exceeded the benchmark figure of 1.00 and rose to an all time high of 11.90 in 2006 . Holding reserves beyond the recommended benchmarks will, other things being equal, probably reduce an economy's vulnerability to financial crisis. Though, it may do so with diminishing marginal benefit and rising marginal cost. Iyoha (1976)

Since the build up in reserves is driven by country specific as well as exogenous factors, identifying the domestic versus external components of reserves is a key element in assessing the sustainability of the observed levels. This focus also addresses the question of reserve accumulation more thoroughly than by studying a sample of countries with fundamentally different policy regimes, as the IMF (2003) and Gosselin and Parent (2005), among others, does. We consider the case of Nigeria, but the analysis applies to other countries with close economic fundamentals. Abdullateef and Waheed (2010) investigated the impact of changes in the external reserve position of Nigeria on domestic investment, inflation rate and exchange rate. Using a combination of ordinary least square (OLS) and vector error correction (VEC) methods, it was observed that change in external reserves in the country only influences foreign direct investment (FDI) and exchange rates and no influence of it was found on domestic investment and inflation rates. They suggested that there is the 
need for broader reserve management strategies aimed at maximizing the gains from oil export revenue by utilizing more of these resources to boost domestic investment. 


\section{ARE NIGERIAN RESERVES EXCESS? AN INFORMAL METHOD}

The Guidotti-Greenspan rule states that a country's reserves should equal short-term external debt (one-year or less maturity), implying a ratio of reserves-to-short term debt of 1.

Using the Greenspan-Guidotti test of reserve adequacy the Nigerian external reserves will be tested to check if it is excess or not. The rule of thumb says that the reserves level should not exceed the level of the country's external short term debt. The rationale is that countries should have enough reserves to resist a massive withdrawal of short term foreign capital.

In the table below, the result of the Greenspan-Guidotti test of reserve adequacy is shown, it shows that up to 1996 the external reserves of Nigeria was mainly inadequate except in 1979 and 1980 when it was adequate and excess respectively.

From the democratic era (fourth republic, 1999) the external reserves has been mainly excess till date.

Also, table 1 in the appendix shows the opportunity cost of holding excess external reserves by the Nigerian government to check if it is profitable to hold excess reserves rather than investing it in the domestic economy. From the table the returns obtained gotten from external reserves is calculated using the US Treasury bond rate then the returns that would have been gotten from reserves if it were alternatively invested in the domestic economy is derive from the domestic interest rate and the result compared with the external returns.

It is observed that the returns in the domestic economy is larger than that of the external returns in various years except in 1979 up to 1981 when the external benefit exceeded the domestic benefit. This means that the Nigerian government have over the years been losing reasonable amount of resources that would have accrued if the reserve was domestically utilized. It is also pertinent to note as shown, in the last column, the amount of resources spent on external debt servicing yearly while excess reserves is stocked at the rate of returns lower than what we spend on debt servicing.

TABLE SHOWING THE GREENSPAN-GUDOTTI RESERVE ADEQUACY FOR NIGERIA

\begin{tabular}{|c|c|c|c|c|}
\hline YEAR & S/T DEBT & RESERVES & Ratio & REMARK \\
\hline 1970 & 269602000 & 223498270 & 0.828993 & INADEQUATE \\
\hline 1971 & 309254000 & 431942336 & 1.396724 & OPTIMAL \\
\hline 1972 & 349948000 & 390711307 & 1.116484 & OPTIMAL \\
\hline 1973 & 574168000 & 622853542 & 1.084793 & OPTIMAL \\
\hline 1974 & 606829000 & 5708969937 & 9.407873 & EXCESS \\
\hline 1975 & 543746000 & 5665692686 & 10.41974 & EXCESS \\
\hline 1976 & 431560000 & 5256783772 & 12.18089 & EXCESS \\
\hline 1977 & 2161157000 & 4335986546 & 2.006326 & EXCESS \\
\hline 1978 & 2446471000 & 2028806093 & 0.829279 & INADEQUATE \\
\hline 1979 & 2283000000 & 5899641163 & 2.584162 & EXCESS \\
\hline 1980 & 3553069000 & $1.064 \mathrm{E}+10$ & 2.994534 & EXCESS \\
\hline 1981 & 4427231000 & 4168453297 & 0.941549 & INADEQUATE \\
\hline 1982 & 2534737000 & 1926433882 & 0.760013 & INADEQUATE \\
\hline 1983 & 5058910000 & 1251986645 & 0.247482 & INADEQUATE \\
\hline 1984 & 5744422000 & 1674113909 & 0.291433 & INADEQUATE \\
\hline 1985 & 4994467000 & 1891868246 & 0.378793 & INADEQUATE \\
\hline 1986 & 3681133000 & 1349903025 & 0.366709 & INADEQUATE \\
\hline 1987 & 1567645000 & 1497832059 & 0.955466 & INADEQUATE \\
\hline 1988 & 1546629000 & 932989777 & 0.603241 & INADEQUATE \\
\hline 1989 & 464772000 & 2041078372 & 4.391569 & EXCESS \\
\hline 1990 & 1503580000 & 4128789621 & 2.745973 & EXCESS \\
\hline 1991 & 858928000 & 4678023330 & 5.446351 & EXCESS \\
\hline 1992 & 2209606000 & 1196052750 & 0.541297 & INADEQUATE \\
\hline 1993 & 3993676000 & 1640443739 & 0.41076 & INADEQUATE \\
\hline 1994 & 4826464000 & 1649172399 & 0.341694 & INADEQUATE \\
\hline 1995 & 5651190000 & 1709113524 & 0.302434 & INADEQUATE \\
\hline 1996 & 5676113000 & 4329391830 & 0.762739 & INADEQUATE \\
\hline 1997 & 5528649000 & 7781250308 & 1.407442 & OPTIMAL \\
\hline 1998 & 6564497000 & 7298545697 & 1.111821 & OPTIMAL \\
\hline 1999 & 6519900000 & 5649725440 & 0.866536 & INADEQUATE \\
\hline 2000 & 1119993000 & 10099448198 & 9.017421 & EXCESS \\
\hline 2001 & 1642817000 & 10646598366 & 6.480696 & EXCESS \\
\hline 2002 & 2270168000 & 7566806238 & 3.333148 & EXCESS \\
\hline 2003 & 3349994000 & 7415087386 & 2.213463 & EXCESS \\
\hline 2004 & 5245750000 & 17256543970 & 3.289624 & EXCESS \\
\hline 2005 & 1836100000 & 28632051719 & 15.59395 & EXCESS \\
\hline & & & & \\
\hline
\end{tabular}




\begin{tabular}{|l|c|c|c|c|}
\hline 2006 & 3890000000 & 42735469033 & 10.98598 & EXCESS \\
\hline 2007 & 4944000000 & 51907034587 & 10.499 & EXCESS \\
\hline 2008 & 7456000000 & 53599283557 & 7.188745 & EXCESS \\
\hline 2009 & 3514000000 & 45509822740 & 12.951 & EXCESS \\
\hline 2010 & 4214000000 & 35339252200 & 8.386154 & EXCESS \\
\hline 2011 & 3321120000 & 43211294000 & 10.531657 & EXCESS \\
\hline \multicolumn{5}{|l}{} \\
\hline
\end{tabular}

Source: World Bank statistical data, and computed by the authors.

\section{MODEL SPECIFICATION}

In the micro level we have income (Y) to be the function of consumption $(\mathcal{O}$ and savings (S) which is mathematically represented as

$\mathrm{Y}=\mathrm{f}(\mathrm{C}, \mathrm{S})$

$\mathrm{Y}=\mathrm{C}+\mathrm{S}$ 1

But in the macro level, three sector and open economy, which Nigeria is one, national income is a function of private consumption, $\mathrm{C}$ investment expenditure, I government or public expenditure, $\mathrm{G}$ as well as net international trade (i.e. export less import) this is mathematically represented as

$\mathrm{Y}=\mathrm{f}(\mathrm{C}, \mathrm{I}, \mathrm{G}(\mathrm{X}-\mathrm{M})$

$\mathrm{Y}=\mathrm{C}+\mathrm{I}+\mathrm{G}+(\mathrm{X}-\mathrm{M})$ .2

Since external reserves yields returns this work assumes it to be investment and incorporate it with investment expenditure but separately to assess it contribution or impact to the level of national income (domestic economy), measured by Gross Domestic Product (GDP) in Nigeria and compare it with what domestic investment contributes to Nigerian economy.

In this work,

$\mathrm{Y}$ will be measured by gross domestic product (GDP)

I will be measured by gross fixed capital formation (GFCF) as domestic investment (DINVST)

$\mathrm{C}$ will be measured by private consumption (PTCON)

$\mathrm{G}$ will be measured by public consumption or expenditure (PUCON) while

(X-M) will be measured by the difference between export and import as net international trade (NIT)

Therefore for the purpose of this study, we will use the understated models to check the hypotheses of this research work;

$\mathrm{GDP}=\mathrm{f}(\mathrm{PTCON}, \mathrm{DINVST}, \mathrm{RES}$, PUCON, NIT $)$

Where;

Res $=$ external reserves

GDP $=$ Gross Domestic Product

$\mathrm{PTCON}=$ private consumption

NIT $=$ net international trade

PUCON = government expenditure

DINVST $=$ level of domestic investment.

Also, domestic investment (DINVST) is a function of national income (measured by GDP) interest rate (INTR), government expenditure (Ge), private consumption (ptcon) External reserves (Res)

DINVST $=\mathrm{f}(\mathrm{GDP}, \mathrm{INTR}$, PUCON, PTCON, Res $)$

\section{MODEL ESTIMATION PROCEDURE}

To investigate the level of Nigerian external reserves a simple OLS, multiple regression analysis will be used and the model will be estimated thus:

$\mathrm{GDP}_{\mathrm{t}}=\mathrm{a}_{0}+\mathrm{a}_{1}$ PTCON $_{\mathrm{t}}+\mathrm{a}_{2}$ DINVST $_{\mathrm{t}}+\mathrm{a}_{3}$ RES $_{\mathrm{t}}+\mathrm{a}_{4}$ PUCON $_{\mathrm{t}}+\mathrm{a}_{5} \mathrm{NIT}_{\mathrm{t}}+£ \ldots \ldots \ldots \ldots . .1$

Where;

$\mathrm{RES}_{\mathrm{t}}=$ reserves at time $\mathrm{t}$

GDP $=$ Gross Domestic Product

PTCON = private consumption

NIT $=$ net international trade

PUCON =government expenditure

DINVST $=$ domestic investment. 


$$
\begin{aligned}
& £=\text { error term } \\
& a_{1}, a_{2}, a_{3}, a_{4}, a_{5}=\text { parameter estimators (coefficient) } \\
& a<>0, a_{1}<>0, a_{2}>0, a_{3}<>0, a_{4}>0, a_{5}<>0
\end{aligned}
$$

2. To check the effect of reserves on domestic investment we use the model below;

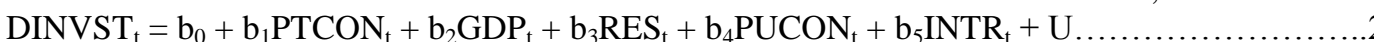

Where;

Intr $=$ interest rate

$\mathrm{U}=$ error term

Other variables as already defined.

$\mathrm{b}_{1}, \mathrm{~b}_{2}, \mathrm{~b}_{3}, \mathrm{~b}_{4}, \mathrm{~b}_{5}=$ parameter estimators (coefficient)

$\mathrm{b}<>0, \mathrm{~b}_{1}<>0, \mathrm{~b}_{2}>0, \mathrm{~b}_{3}<>0, \mathrm{~b}_{4}>0, \mathrm{~b}_{5}<0$

The period taken into consideration is from 1970 to 2010 studying the impact of external reserve on the Nigerian domestic economy.

\section{TEST OF TIME SERIES PROPERTIES}

When estimating a model that involves time series variables, the first thing we need to make sure is that either all time series variables in the model are stationary or they are co integrated, which means that they are integrated of the same order and errors are stationary, in which case the model defines a long run equilibrium relationship among the co integrated variables. Therefore, a co integration test generally takes two steps. The first step is to conduct a unit root test on each variable to find the order of integration. If all variables are integrated of the same order, the second step is to estimate the model, also called a "co integrating equation," and test whether the residual of the model is stationary.

Therefore, we will test for stationary level of each of the variable used in our model using Augmented DickeyFuller (ADF) and Phillip-perron test which the result is shown below;

\begin{tabular}{|l|l|l|l|l|}
\hline VARIABLE & ADF & LEVEL & PHILLIP-PERRON & LEVEL \\
\hline GDP & 6.0559 & $\mathrm{I}(\mathrm{O})$ & 6.0559 & $\mathrm{I}(\mathrm{O})$ \\
\hline EXTRES & 3.6648 & $\mathrm{I}(\mathrm{II})^{*}$ & 3.6648 & $\mathrm{I}(\mathrm{II})^{*}$ \\
\hline DINVEST & 6.6696 & $\mathrm{I}(\mathrm{O})$ & 14.4335 & $\mathrm{I}(\mathrm{O})$ \\
\hline NIT & $\mathrm{I}(\mathrm{O})$ & 4.3035 & $\mathrm{I}(\mathrm{O})$ \\
\hline PUCON & 4.6233 & $\mathrm{I}(\mathrm{O})$ & 13.6950 & $\mathrm{I}(\mathrm{O})$ \\
\hline PCON & 5.3110 & $\mathrm{I}(\mathrm{I})^{*}$ & 2.6331 & $\mathrm{I}(\mathrm{O})^{* *}$ \\
\hline INTR & 4.5904 & $\mathrm{I}(\mathrm{I})$ & 10.3547 & $\mathrm{I}(\mathrm{I})$ \\
\hline
\end{tabular}

Base on the result of unit root above, it is seen that three variables (private consumption, interest rate and external reserves) in the model are not stationary. This means that there is need to conduct a co integration test to check if there is a long run relationship among the variables in the model. The result of the co integration test shows that there are six (6) co integrating equations at both 5\% and $1 \%$ levels as the trace statistic values are greater than the critical values at both $5 \%$ and $1 \%$ levels. This means that the variables are co integrated and hence, there is existence of long run relationship among them, therefore we can go ahead and estimate the over parameterized model and then reduced it to parsimonious model.

\section{Discussion Of Major Findings}

The result of the parsimonious model 1, shows that the impact of external reserves on the level of national productivity or income, measured in GDP, reveals that Nigeria's external reserves (RES) has a negative impact on the level of boom in the economy and it is significant, meaning that the huge amount of reserve pile up in the international money market in other to have a good reputation for the country's liquidity level for borrowing has a slow down effect on the level of economic activities in the domestic economy compare to the domestic investment which is also significant but has a direct relationship, promote economic boom in the country.

An increase in the level of investment will cause a $135.127 \%$ increase in the level of economic growth in the Nigerian economy. This shows that the excess reserves in the international money market would have been used to invest in the domestic economy to achieve economic growth. In the case of private consumption, the negative impact of this variable could be explain by the fact that most of the Nigerian citizen spent their income on imported goods and services which in turn slows down the level of economic productivity in the nation while promoting that of the trading partner country, this variable is also very significant, public expenditure in the nation promotes the level of productivity and off course the net international trade variable, though not significant, indicates that Nigeria buys more than what they produce and offer to sell in the international markets, the existing capacity measured by lag of GDP shows that it increase the level of productivity in the current year this will give a positive multiplier effect if the part of the external reserves is 
withdrawn to invest in the domestic economy rather than keeping in the foreign banks that will yield little returns to the Nigerian economy.

The ECM which measures the speed of adjustment shows the long run relationship of the model and if the system is distorted it will be corrected by more than $50 \%$ in the next year and this is very good as any corrective measures will have a quick response to the economy and it is significant with the expected negative sign.

From the adjusted R-squared, we observed that $90.7 \%$ of variation in the domestic economy is explain by the model and only $9.3 \%$ of changes in the economy is caused by variables outside the model otherwise known as error term. This shows a good fitness, also the Durbin-Watson result shows that there is no serial correlation in the model and thus the result should be accepted. The F-statistic indicates that the model is statistically significant since the value is greater than the tabulated F-ratio.

However, the second estimated model, which shows the relationship that external reserves has with the domestic investment in the country, gives a similar result in the private consumption and external reserves as variables that negatively influence the internal investment. The reasons are not far fetch as Nigerians citizens prefer imported goods and services to made in Nigeria goods and services. This habit retards the growth of the manufacturing sector and hence the domestic investment.

The public expenditure variable indicates that the Nigerian government spent more on recurrent expenditure and irrelevant affairs leaving less to be invested in the capital projects or investment this gives the negative sign of public consumption in the model and is very significant in the model. The long run relationship (ECM) shows that more than 60\% error in the system will be corrected by any reform made toward improving the economy and also have the expected negative sign.

The entire result is accepted given the Durbin-Watson result of 2.2 which shows no serial correlation, the goodness of fit of $84.6 \%$ and f-ratio of 29.19 (higher than the F-ratio tabulated of 2.61).

\section{Summary Of Major Findings}

After extensively assessing the level of Nigerian external reserves and the concepts of reserves adequacy, the following are established,

i. From the rule of thumb criteria of reserves adequacy we discover that the Nigerian external reserves have been excess over the years.

ii. The review of literature shows that Nigeria needs huge reserves to maintain a fixed exchange rate policy.

iii. Keeping excess reserves negatively influence the level of domestic investment in Nigeria as the excess reserves would have been invested in the domestic economy.

iv. The returns derive from external reserves is lower than what would have been obtained from investing it in the domestic economy hence, the real cost of keeping excess reserves is high.

v. Millions of US dollar is spent yearly on external debt servicing by Nigerian government while the returns on reserves is low compare to the amount on servicing.

vi. Public expenditure in Nigeria does not promote domestic investment.

Base on the findings we recommend the following,

1. The Nigerian government should allow the exchange rate to be flexible since a fixed exchange rate always attracts huge reserves to maintain it.

2. The federal government should keep reasonable reserves and invest the excess reserves in the domestic economy while policies should be made to mandate the monetary authorities not to swaps high-yield domestic assets for low-yield foreign ones.

3. Since the returns derive from external reserves is lower than the resources spent on external debt servicing the federal government should reduce the level of external borrowing and rather tap from the external reserves for domestic spending.

4. Having discovered that government expenditure does not promote investment, we recommend that government should make reforms to minimize the cost of recurrent governance and social spending so that more funds will be available to channel to investment.

\section{Conclusion}

The main intention of this work was to examine the impact of external reserves on the Nigerian economy, in order to do this, we use both qualitative and quantitative method to assess the reserve adequacy of Nigeria, the opportunity cost of keeping reserves in the external banks rather than in the domestic economy and compared the cost of external debt servicing with the returns derived from external reserves. 
As a result of these, we estimated two models using econometric, multiple regression analysis and use domestic economy, measured by GDP and domestic investment, measured by Gross fixed capital formation (GFCF) as dependent variables for each of the models, after testing for the stationary level of each of the variables and conducting co integration, we discover that the variables are co integrated. Therefore we proceeded to the over parameterized model which then took us to the parsimonious model. We estimated the error correction model (ECM).

The results show that external reserves negatively influence the level of domestic economic productivity and investment. The hypothesis was stated and tested that there is a negative relationship between Nigeria's external reserves and the domestic economy.

Therefore, the Nigerian government should reduce the level of excess reserves and rather use it for investment in the domestic economy.

\section{APPENDIX}

\begin{tabular}{|c|c|c|c|c|c|c|c|}
\hline YEAR & $\begin{array}{l}\text { BOND } \\
\text { RATE } \\
\end{array}$ & RES & $\begin{array}{l}\text { Int'l } \\
\text { returns } \\
\end{array}$ & INTR & dom.rets & $\begin{array}{l}\text { Opportunity } \\
\text { cost }\end{array}$ & $\begin{array}{l}\text { ext.debt ser. } \\
\$ \mathrm{~m}\end{array}$ \\
\hline 1970 & 6.39 & 156.58 & 1000.546 & 8 & 1252.64 & -252.094 & 95556000 \\
\hline 1971 & 4.64 & 281.38 & 1305.603 & 10 & 2813.8 & -1508.2 & 94469000 \\
\hline 1972 & 4.82 & 243.58 & 1174.056 & 10 & 2435.8 & -1261.74 & 95261000 \\
\hline 1973 & 7.16 & 377.98 & 2706.337 & 10 & 3779.8 & -1073.46 & 228669000 \\
\hline 1974 & 7.72 & 3452.3 & 26651.76 & 10 & 34523 & -7871.24 & 192011000 \\
\hline 1975 & 6.37 & 3583.7 & 22828.17 & 9 & 32253.3 & -9425.13 & 269835000 \\
\hline 1976 & 5.62 & 3286.3 & 18469.01 & 10 & 32863 & -14394 & 400272000 \\
\hline 1977 & 5.7 & 2814.5 & 16042.65 & 6 & 16887 & -844.35 & 138130000 \\
\hline 1978 & 7.68 & 1298.9 & 9975.552 & 11 & 14287.9 & -4312.35 & 148871000 \\
\hline 1979 & 9.77 & 3059.8 & 29894.25 & 9.5 & 29068.1 & 826.146 & 391800000 \\
\hline 1980 & 10.75 & 5462 & 58716.5 & 10 & 54620 & 4096.5 & 1150772000 \\
\hline 1981 & 13.16 & 2441.6 & 32131.46 & 11.75 & 28688.8 & 3442.656 & 1788841000 \\
\hline 1982 & 11.1 & 1043.3 & 11580.63 & 11.5 & 11997.95 & -417.32 & 2086475000 \\
\hline 1983 & 8.86 & 224.4 & 1988.184 & 13 & 2917.2 & -929.016 & 2561869000 \\
\hline 1984 & 9.91 & 710.1 & 7037.091 & 11.75 & 8343.675 & -1306.58 & 4064251000 \\
\hline 1985 & 7.76 & 1657.9 & 12865.3 & 12 & 19894.8 & -7029.5 & 4425445000 \\
\hline 1986 & 6.07 & 2836.6 & 17218.16 & 19.2 & 54462.72 & -37244.6 & 2050078000 \\
\hline 1987 & 6.33 & 7504.589 & 47504.05 & 17.6 & 132080.8 & -84576.7 & 1106408000 \\
\hline 1988 & 7.17 & 5229.105 & 37492.68 & 24.6 & 128636 & -91143.3 & 2210434000 \\
\hline 1989 & 7.91 & 3047.619 & 24106.67 & 27.7 & 84419.05 & -60312.4 & 2117490000 \\
\hline 1990 & 7.36 & 4541.448 & 33425.06 & 20.7 & 94007.97 & -60582.9 & 3335543000 \\
\hline 1991 & 5.54 & 4149.298 & 22987.11 & 20.8 & 86305.39 & -63318.3 & 2944753000 \\
\hline 1992 & 3.75 & 1554.607 & 5829.778 & 31.2 & 48503.75 & -42674 & 3749026000 \\
\hline 1993 & 3.33 & 1429.59 & 4760.535 & 36.09 & 51593.9 & -46833.4 & 1490998000 \\
\hline 1994 & 4.98 & 9009.11 & 44865.37 & 21 & 189191.3 & -144326 & 1871671000 \\
\hline 1995 & 5.69 & 1611.11 & 9167.216 & 20.79 & 33494.98 & -24327.8 & 1832904000 \\
\hline 1996 & 5.23 & 3403.91 & 17802.45 & 20.86 & 71005.56 & -53203.1 & 2509063000 \\
\hline 1997 & 5.36 & 7222.215 & 38711.07 & 23.32 & 168422.1 & -129711 & 1415795000 \\
\hline 1998 & 4.85 & 7107.5 & 34471.38 & 21.34 & 151674.1 & -117203 & 1331880000 \\
\hline 1999 & 4.78 & 5424.6 & 25929.59 & 27.19 & 147494.9 & -121565 & 1063415000 \\
\hline 2000 & 5.85 & 9386.1 & 54908.69 & 21.55 & 202270.5 & -147362 & 1844897000 \\
\hline 2001 & 5.21 & 10267.1 & 53491.59 & 21.34 & 219099.9 & -165608 & 2560613000 \\
\hline 2002 & 4.86 & 7681.1 & 37330.15 & 30.19 & 231892.4 & -194562 & 1489896000 \\
\hline 2003 & 4.56 & 7467.78 & 34053.08 & 22.88 & 170862.8 & -136810 & 1642115000 \\
\hline 2004 & 4.03 & 16955.02 & 68328.73 & 20.82 & 353003.5 & -284675 & 1724814000 \\
\hline 2005 & 3.43 & 28279.06 & 96997.18 & 19.49 & 551158.9 & -454162 & 8862746000 \\
\hline 2006 & 3.23 & 42298.11 & 136622.9 & 18.7 & 790974.7 & -654352 & 6813729000 \\
\hline 2007 & 4.01 & 51333.15 & 205845.9 & 18.24 & 936316.7 & -730471 & 1250589000 \\
\hline 2008 & 4.05 & 53000.36 & 214651.5 & 21.18 & 1122548 & -907896 & 590671000 \\
\hline 2009 & 4.008 & 42382.49 & 169869 & 22.9 & 970559 & -800690 & 509515000 \\
\hline
\end{tabular}




\begin{tabular}{|l|l|l|l|l|l|l|l|}
\hline 2010 & 4.802 & 32339.25 & 155293.1 & 21.85 & 706612.6 & -551320 & \\
\hline
\end{tabular}

TABLE 2: PASIMONIOUS MODEL 1 ESTIMETED RESULT DEPENDENT VARIABLE: GROSS DOMESTIC PRODUCT (GDP) METHOD: LEAST SQUARES

SAMPLE: 1970 - 2010

\begin{tabular}{|c|c|c|c|}
\hline VARIABLES & COEFFICIENT & STD.ERROR & T-STATISTIC \\
\hline C & 196983.3 & 4020090 & 0.049000 \\
\hline RES(-2) & -1712.117 & 639.160 & -2.658698 \\
\hline DINVST & 135.1270 & 17.65452 & 7.653961 \\
\hline PTCON & -18.81216 & 5.662890 & -3.322008 \\
\hline PUCON & 47.28333 & 16.34093 & 2.893552 \\
\hline NIT & -20.38129 & 13.19945 & -1.544101 \\
\hline GDP(-1) & 2.046435 & 6.579748 & 0.311020 \\
\hline ECM(-1) & -0.514502 & DURBIN-WATSON: & -2.231567 \\
\hline $\begin{array}{l}\text { R-SQUARED: } \\
0.925226\end{array}$ & $\begin{array}{l}\text { ADJ.R-SQUARED: } \\
\text { 0.907779 }\end{array}$ & $\begin{array}{l}\text { F-STATISTIC: } \\
53.02993\end{array}$ \\
\hline
\end{tabular}

TABLE 3: PASIMONIOUS MODEL 2 ESTIMATED RESULTS

DEPENDENT VARIABLE: DOMESTIC INVESTMENT (DINVST)

METHOD: LEAST SQUARES

SAMPLE: $1970-2010$

\begin{tabular}{|c|l|l|l|}
\hline VARIABLE & COEFFICIENT & STD. ERROR & T-STATISTIC \\
\hline C & 10336.03 & 16583.85 & 0.623259 \\
\hline DGDP & 0.003627 & 0.0211347 & 0.169908 \\
\hline DGDP(-1) & 0.250712 & 0.031368 & 7.994926 \\
\hline DRES & -1690849 & 4.232491 & -3.994926 \\
\hline DRES(-2) & 9.384663 & 4.600455 & 2.039942 \\
\hline DPUCON & -0.546750 & 0.102861 & -5.315447 \\
\hline DPTCON & -0.075385 & 0.029152 & -2.585937 \\
\hline ECM(-1) & -0.656192 & 0.223431 & -2.936881 \\
\hline R-SQUARED & ADJUSTED R-SQUARED & DURBIN-WATSON & F-STATISTIC \\
0.87564 & 0.845689 & 2.223431 & 29.18504 \\
\hline
\end{tabular}

\section{Reference}

[1]. Abdullateef and Waleved (2010). External Reserve holdings in Nigeria: Implications for investment, inflation and exchange rage: Journal of Economics and International finance vol. 2 (9).

[2]. Aizenmann, J. (2002) “The High Demand for International Reserves in the Far East: What's Going On?" Working Paper, UC Santa Cruz and the NBER; Dartmouth College.

[3]. Aizenman, Joshua \& Marion, Nancy P., 2003. "International Reserve Holdings with Sovereign Risk and Costly Tax Collection," Santa Cruz Center for International Economics, Working Paper Series qt9s7978n1, Center for International Economics, UC Santa Cruz

[4]. Aizenman, J. \& Marion, N. (2003). The high demand for international reserves in the Far East: What is going on? Journal of Japanese and International Economies, 17:370-400.

[5]. Aizenman J, Marion N (2004). International Reserve Holdings with Sovereign Risk and costly tax collection” Economic. Journal. 24: 357370.

[6]. Aligwekwe, E.F. (1978), "Nigeria's Experience in the Management of International Reserves: 1960 -1976, being a Dissertation, submitted to the Department of Economics, University of Ibadan, Ibadan, Nigeria.

[7]. Central Bank of Nigeria Statistical Bulletin, 2010

[8]. Greenspan, A. (1999). Currency reserves and debt. Remarks before the World Bank conference on recent trends in reserves management, Washington D. C

[9]. Gosselin, M. \& Parent, N. (2005). An empirical analysis of foreign exchange reserves in emerging Asia”. Bank of Canada Working Ottawa, Canada, 38.

[10]. Iyoha, M.A. (1976), "Demand for International Reserves in Less DevelopedCountries: A Distributed Lag Specification", The Review of Economics and Statistics,

[11]. Vol. 58, No.3, pp. 351-355.

[12]. International Monetary Fund (2003). Three current policy issues in developing countries, World Economic Outlook, Building Institution

[13]. Nda, A. M. (2006). Effective reserves management in Nigeria: Issues, challenges and prospect, Central Bank of Nigeria Bullion, 30(3).

[14]. Soludo, C. C. (2005). The challenges of foreign exchange reserve management in Nigeria, A keynote address delivered at the UBS Eleventh Annual Reserve Management Seminar, Wolfs, 2-10 June.

[15]. Odozi, V. (1986), 'Foreign Exchange Management: The Role of the Central Bank of Nigeria', CBN Bullion, Vol. 10 , No 3, p. 17 - 22.

[16]. Osabuohien E. S. C., Egwakhe A. J(2008). "External Reserve and the Nigerian Economy: The Dual Folded Debate"/ AJBER Vol. 3 Nos. 2 \& $328-41$ 